\title{
Taxation of Cryptocurrencies from the Danish and Swedish Perspectives
}

\author{
Kjærsgaard, Louise Fjord ; Arfwidsson, Autilia
}

Document Version

Final published version

Published in:

Intertax

Publication date:

2019

License

Unspecified

Citation for published version (APA):

Kjærsgaard, L. F., \& Arfwidsson, A. (2019). Taxation of Cryptocurrencies from the Danish and Swedish Perspectives. Intertax, 47(6/7), 620-634.

Link to publication in CBS Research Portal

\section{General rights}

Copyright and moral rights for the publications made accessible in the public portal are retained by the authors and/or other copyright owners and it is a condition of accessing publications that users recognise and abide by the legal requirements associated with these rights.

\section{Take down policy}

If you believe that this document breaches copyright please contact us (research.lib@cbs.dk) providing details, and we will remove access to the work immediately and investigate your claim.

Download date: 26. Apr. 2023

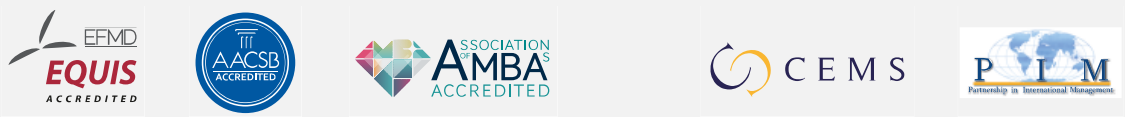




\title{
Taxation of Cryptocurrencies from the Danish and Swedish Perspectives
}

\author{
Louise Fjord Kjærsgaard* \& Autilia Arfwidsson ${ }^{* *}$
}

\begin{abstract}
The authors analyse the current classification of cryptocurrencies from the Danish and Swedish domestic income tax perspectives. Cryptocurrencies are analysed as they are typically applied in practice, where a categorization is made between coins, utility tokens, security tokens and asset tokens. In particular, it is concluded that despite the economic differences of different cryptocurrencies, they generally fall outside the scope of Danish and Swedish lex specialis regulation on taxation of capital gains and losses from the sale of certain assets, for example, shares and claims in currency. In both countries, there appears to be a presumption that most cryptocurrencies should be taxed as assets held for investment and speculative purposes. It is argued that such an approach is problematic not only in relation to the principle of neutrality, but also because it creates a barrier to realizing the economic potential of cryptocurrencies. The authors conclude that (1) the classification of cryptocurrencies poses challenges and uncertainty for tax purposes due to the lack of a regulatory framework, the absence of common definitions and the diverse technical structure of tokens and coins and (2) the classification for Danish and Swedish tax law purposes should be based on a case-by-case assessment of the specific cryptocurrency.
\end{abstract}

\section{INTRODUCTION}

Digitalization has revolutionized many areas of today's globalized society. One of the developments is the introduction of cryptocurrencies. Apart from functioning as an alternative to standardized national currencies, the underlying technology also includes applications that go beyond the functions of digital money. Supporters of this new technology predict a revolution in how value will be exchanged in the future. ${ }^{1}$

However, the new technology raises several legal questions - also in the area of taxation. Taxpayers and tax authorities are faced with the challenge of having to understand and classify transactions via technology, which falls outside the scope of traditional streams of financial commerce. ${ }^{2}$ Consequently, the classification of cryptocurrencies can vary significantly depending on the purpose and functions of the specific cryptocurrency. Individual facts and circumstances of the taxpayer may also affect the classification. As the classification of a transaction usually affects how the income is taxed, it is critical to thoroughly analyse the tax consequences before issuing or investing in cryptocurrencies.

The aim with this article is to, first, identify issues related to the classification of cryptocurrencies and, second, analyse the identified issues from a Danish and Swedish income tax perspective. ${ }^{3}$ This article contributes to the international tax literature with a Nordic perspective on the taxation of cryptocurrencies in domestic law. As the legal sources on cryptocurrencies are sparse and the income tax laws of both jurisdictions are relatively similar, a joint analysis of the income taxation allows for a more in-depth analysis of different classification issues. ${ }^{4}$ This is

\section{Notes}

* Ph.D. Scholar at Copenhagen Business School; Senior Associate at CORIT Advisory. Email: 1fk.law@cbs.dk.

** PhD Scholar at Uppsala University. Stiftelsen Centrum för Skatterätt has funded the research, for which the author is grateful. Email: autilia.arfwidsson@ @ur.uu.se.

1 See further P. Boucher, European Parliamentary Research Service, How Blockchain Technology Could Change Our Lives, PE 581.948 (2017); J. Parra-Moyano \& O. Ross, KYC Optimization Using Distributed Ledger Technology, 59 Bus. \& Info. Systems Eng'g 6 (2017); D. Tapiscott \& A. Tapscott, Blockchain Revolution: How the Technology Bebind Bitcoin and Other Cryptocurrencies Is Changing the World (Portfolio/Penguin 2017).

2 See e.g. F. Rubinstein \& G. G. Vettor Brazil, Taxation of Investments in Bitcoins and Other Virtual Currencies: International Trends and the Brazilian Approach, 20 Derivs. \& Fin. Instrums. 3 (2018); A. Bal, VAT Treatment of Initial Coin Offerings, 29 Int'l VAT Monitor 3 (2018), and the same author in Blockchain, Initial Coin Offerings and Other Developments in the Virtual Currency Market, 20 Derivs. \& Fin. Instrums. 2 (2018), Bitcoin Transactions: Recent Tax Developments and Regulatory Responses, 17 Derivs. \& Fin. Instrums. 5 (2015), US Regulatory Framework for Cryptocurrency Transactions, 20 Derivs. \& Fin. Instrums. 5 (2018); S. Meiklehohn, M. Pomarole et al., A Fistful of Bitcoins: Characterizing Payments Among Men with No Names, in Proceedings of the 2013 Conference on Internet Measurement Conference (ACM 2013).

Although cryptocurrencies have been subject to debate in relation to tax evasion, this is outside the scope of this article

The legal systems of Denmark and Sweden undoubtedly have differences, but - allegedly - it still makes sense to speak of Denmark and Sweden as part of the Nordic legal systems to constitute a (distinct) legal family as discussed by J. Husa, K. Nuotio \& H. Pihlajamäki, Nordic Law - Between Tradition and Dynamism in Nordic Law - Between Tradition and Dynamism 1-40 (J. Husa, K. Nuotio \& H. Pihlajamäki eds, Intersentia 2007). However, it should also be acknowledged that the classification and division into legal families can be difficult and subject to criticism, as correctly pointed out by E. Kristofferson, Comparative Studies of National Law in the EU Harmonized VAT, 1 Nordic Tax J. 29 et seq. (2015), at 
not a comparative analysis in the traditional sense, but could be described as a functional micro-level comparison with respect to a specific legal problem, ${ }^{5}$ namely how cryptocurrencies should be classified under Danish and Swedish income tax law.

In section 2 of this article, an overview of the functions and essential features of cryptocurrencies is provided. Cryptocurrencies characterized as coins, utility tokens, security tokens and asset tokens are then analysed in section 3 For the purpose of structuring and delimiting the analysis of the classification of coins and tokens, the analysis is based on a specific example involving a transfer of a cryptocurrency between two parties. Section 4 includes de lege ferenda considerations on the classification of cryptocurrencies in relation to the principle of neutrality. Finally, section 5 provides a succinct conclusion.

\section{Cryptocurrencies: Relevance AND BACKGROUND}

Cryptocurrencies are built on blockchain technology, a digital innovation that, according to optimists, will revolutionize the way we look at money, the way we exchange value and the functioning economy at large. ${ }^{6}$ Blockchain technology was first described approximately ten years ago in a white paper titled Bitcoin: A Peer-to-Peer Electronic Cash System, written by a person or persons under the pseudonym Satoshi Nakamoto. ${ }^{7}$ Today, blockchain technology comes in various forms. ${ }^{8}$ The technology can be described as a peer-to-peer network, offering a record-keeping function similar to a trusted intermediary (e.g. a bank) but without a centralized architecture. ${ }^{9}$ A peer-to-peer network is an extensive network of nodes (users) that share many features of distributed systems. ${ }^{10}$ In contrast to distributed networks, peer-to-peer networks are generally loose and flexible organizations since users typically are autonomous personal computers. Dependency on the will of individual owners of the computers results in the network typically having a high stream of users entering and exiting the system. This can be managed through incentives implemented in the underlying protocol of the network. ${ }^{11}$ Each user of a blockchain-based cryptocurrency typically has a digital 'wallet' with a private and a public key that use an encryption technology called cryptography, which - depending on the specific type of blockchain - provides privacy as well as open source accessibility. $^{12}$

Transactions based on blockchain technology are processed in three main steps. In simplified terms, a user first sends a transaction request, which is broadcasted to other users holding copies of the record-keeping ledger. Depending on the design of the specific blockchain, all or some users have a copy of the ledger. Second, the network validates the transaction by users solving mathematical algorithms. Users are generally incentivized to verify transactions by rewards - typically in the form of transaction fees and/or a specific amount of the newly created currency. Finally, the verified transaction is synchronized with all other transactions. Jointly, the transactions become a new block of information that will be added to the existing blockchain. ${ }^{13}$ As a consequence, blockchain technology allows transparent, direct and secure transfers of value without being dependent on a central authority.

Cryptocurrencies is one of the various digital assets that may be linked to a blockchain. There is currently no common international definition of the term cryptocurrency. However, in general, two main categories of cryptocurrencies can be distinguished: coins and tokens. ${ }^{14}$ In this article, the term cryptocurrency is used to refer to both categories.

Coins are generally powered by separate blockchains which operate independently of other blockchains. They are typically intended to function as an alternative to official national currencies, although, in practice, investment is often done for speculative purposes. Bitcoin and similar cryptocurrencies, such as Litecoin, are examples of coins.

\section{Notes}

M. Bogdan, Concise Introduction to Comparative Law (Europa Law Publishing 2013).

See e.g. Boucher, supra n. 1; Parra-Moyano \& Ross, supra n. 1; Tapiscott \& Tapscott, supra n. 1.

S. Nakamoto, Bitcoin: A Peer-to-Peer Electronic Cash System (2008), https://Bitcoin.org/Bitcoin.pdf (accessed 24 Nov. 2018),

Boucher, supra n. 1.

S. Abiteboul, I. Manolescu et al., Web Data Management - Introduction to Distributed Systems 18-19 (Cambridge University Press 2011).

10 Abiteboul, Manolescu et al., supra n. 9, at 3. A distributed system is defined as a 'piece of software that serves to coordinate the actions of several computers'. Further, the authors argue on p. 14-16 that the most important properties of a distributed system are reliability, scalability, availability and efficiency.

11 See e.g. Chainanalysis Team, Cryptocurrencies Cannot Die (4 Oct. 2017), https://blog.chainalysis.com/cryptocurrencies-cannot-die/ (accessed 4 Oct. 2017). The author argues that the incentives implemented in the protocol of the Bitcoin cash and Bitcoin blockchain effectively eliminates the risks that these cryptocurrencies will die - as long as there are profit-motivated miners in the network.

12 Bal, Blockchain, Initial Coin Offerings and Other Developments in the Virtual Currency Market, supra n. 2, at 2; R. A. Robinson, The New Digital Wild West: Regulating the Explosion of Initial Coin Offerings, Tennessee L. Rev. 10 (2017).

13 Robinson, supra n. 14, at 15-21.

14 See e.g. Bal, Blockchain, Initial Coin Offerings and Other Developments in the Virtual Currency Market, supra n. 2, at 1, where the author categorizes cryptocurrencies as tokens and coins. 
Tokens, are units of value that typically rely on an already existing blockchain. ${ }^{15}$ Apart from working as a means of exchange, tokens can include functions such as voting rights and stakeholder rights. An example of a popular token is Ethers, which is the native token of the Ethereum blockchain. ${ }^{16}$ Tokens may be issued using initial coin offerings (ICOs), which can be described as a new form of crowdfunding, where investors participate by exchanging official currencies or coins to tokens created and issued by the ICO issuer. ${ }^{17}$ Typically, an investor in a token will however not have a legal right to choose repayment of the token from the issuer in an official currency. Since the first ICO in 2012, ICOs have become an increasingly popular means of financing start-up companies. In 2017, crypto start ups raised more capital through ICOs than venture capital. ${ }^{18}$ In contrast to initial public offerings (IPOs), benefits of ICOs include both fundraising at a very early stage of company development and minimization of transaction costs. ${ }^{19}$ Since the beginning of 2018, the funds raised through ICOs have dropped dramatically. ${ }^{20}$ Although there may be several reasons for this decrease, the legal uncertainty caused by the lack of clear regulations - including in the area of taxation - may be a contributing factor. ${ }^{21}$

In an ICO, an issuer sells tokens that may imply different rights and obligations for the issuer and the investor. The structuring possibilities of ICOs are, in principle, infinite which have allowed the development of tokens with a wide range of different terms of conditions. In this article, tokens are categorized as security tokens, utility tokens or asset tokens. ${ }^{22}$

Security tokens grant a potential future return on the invested capital. They can be compared to investment contracts and may include share-like components, such as voting and profit participation rights in the issuing company, or bond-like features, such as repayment and interest obligations. In practice, security tokens may also be hybrids with features of both shares and bonds. $^{23}$

Utility tokens function as a payment method within a network. Typically, they can be exchanged for (future) goods and services within the network of the issuing company. An important distinction between utility tokens and security tokens is that a utility token does not give any promised or perceived return of investment. Utility tokens are intended to increase in value only in correlation with value increase of the goods or services of the issuing company. ${ }^{24}$ Leaving the technical construction aside, the difference between coins and utility tokens is mainly the purpose for which they are created, i.e. as a general payment method versus a payment method within a specific network. This implies that whereas the value of coins is based solely on market supply and demand of the coin itself, the value of a utility token is based on the value of the goods or services within the network of the issuing company. Compared to security tokens, the intended use of utility tokens is more similar to the use of coins. Nonetheless, investment in utility tokens and other cryptocurrencies to a large extent appears to be done for speculative purposes. ${ }^{25}$

Asset tokens represent actual physical assets that have been tokenized. The price paid for the asset token should equal the price of an individualized underlying asset, i.e. a specific piece of gold or a specific house and not 'some gold' or 'a house' equal to the value of the asset token. ${ }^{26}$

In summary, there is a wide range of different cryptocurrencies with diverging features and functions. There is no common approach to define the technology, although distinctions can be made between coins, security tokens, utility tokens and asset tokens. The classification of cryptocurrencies for Danish and Swedish domestic tax purposes are analysed in the foregoing sections based on the distinguishing features of each of these four identified categories: coins, utility tokens, security tokens and asset tokens.

\section{Notes}

15 Bal, Blockchain, Initial Coin Offerings and Other Developments in the Virtual Currency Market, supra n. 2, at 1.

16 The implementation set up follows Vitalik Buterin's white paper published in 2014 and a crowdfunding campaign. Ethereum Blockchain App Platform, https://www.ethereum. org/ether (accessed 3 Dec. 2018).

17 W.A. Kaal \& M. Dell'Erba, Initial Coin Offerings: Emerging Practices, Risk Factors, and Red Flags, FinTech-Handbuch: Digitalisierung, Recht, Finanzen (F. Möslein \& S. Omlor eds, Verlag C.H. Beck 2019).

18 Ibid., at 2.

19 Bal, Blockchain, Initial Coin Offerings and Other Developments in the Virtual Currency Market, supra n. 4, at 5; Kaal \& Dell'Erba, supra n. 17, at 2.

20 Icodata, Funds Raised in 2018, https://www.icodata.io/stats/2018 (accessed 2 Mar. 2019), which shows that during Jan. 2018 more than USD 1.5 billion was raised through ICOs, whereas less than USD 80 million was raised through ICOs in Dec. 2018.

21 Kaal \& Dell'Erba, supra n. 17.

22 Generally, tokens are divided into utility tokens and security tokens, where asset tokens are a sort of security tokens. In this article, asset tokens are in a separate category since they have specific features that affect classification for tax purposes in Sweden and Denmark.

23 T. Sameeh, ICO Basics: The Difference between Security Tokens and Utility Tokens (29 Mar. 2018), https://www.cointelligence.com/content/ico-basics-security-tokens-vs-utilitytokens/ (accessed 3 Dec. 2018).

24 Ibid.

25 J. Adkinsson, Why Bitcoin Is So Volatile, Forbes (9 Feb. 2018), https://www.forbes.com/sites/jayadkisson/2018/02/09/why-bitcoin-is-so-volatile/\#3aa1833639fb (accessed 3 Dec. 2018).

26 J. Rathod, The Rise of Asset-Backed Tokens (17 Jan. 2018), https://medium.com/pecunio/the-rise-of-asset-backed-tokens-90570438261c (accessed 3 Dec. 2018). 


\section{TAX LAW CLASSIFICATION OF CRYPTOCURRENCIES}

\section{I Introduction to Danish and Swedish Income Tax Law}

When comparing the Danish and Swedish income tax systems, many of the fundamental principles that govern the design of the tax systems are shared. For instance, resident taxpayers are subject to income tax which is levied on worldwide income, albeit with certain notable exemptions for corporate taxpayers' permanent establishments and immovable properties abroad. Non-resident taxpayers are subject to tax only on domestic-source income from explicitly listed sources. ${ }^{27}$ Furthermore, both the Danish and the Swedish tax systems are to a large extent based on the net principle, i.e. that all taxpayers are taxed based on an annual assessment of various types of income from which various types of expenses and losses are deducted. ${ }^{28}$ In this respect, both the Danish and Swedish tax systems distinguish between corporate taxpayers and individual taxpayers. Corporate taxpayers are taxed at a rate of $20.6 \%$ in Sweden and $22 \%$ in Denmark. ${ }^{29}$ Individual taxpayers are taxed according to several income categories. In Sweden, income from individual taxpayers is separated into three main categories: business income, employment income and capital income. ${ }^{30}$ In Denmark, there are also several other income categories for individual taxpayers, such as income from shares. ${ }^{31}$ Depending on how an income of an individual taxpayer is classified, different rules on calculating capital gains and deduction rights apply in both Denmark and Sweden.

\subsection{Classification Issues: Preliminary Remarks}

Classification of cryptocurrencies poses challenges for tax purposes due to the lack of a regulatory framework, the absence of common definitions and the diverse technical structure of different tokens or coins. In general, the significance of classification for tax purposes relates to whether a tax system defines income in a global or scheduler way. ${ }^{32}$ As already indicated both the Danish and Swedish tax systems with respect to capital gains have strong similarities with a scheduler tax system, classification is of critical significance. ${ }^{33}$

Classification should be based on the economic attributes of a cryptocurrency, including the rights and obligations this implies for the issuer and investor. Depending on the economic attributes of the specific cryptocurrency, it could potentially be classified as a currency, share, bond or personal property in both Denmark and Sweden. For the purpose of structuring and delimiting the following analysis, the classification of coins and tokens is based on the following example. ${ }^{34}$

Example: Transfer of cryptocurrencies

1. A Co, a limited liability company tax resident in either Denmark or Sweden, sells a coin or issues a token

2. Person B, tax resident in the same jurisdiction as $A C_{0}$, acquires the coin or the issued token by means of an official currency

3. Person B then sells the coin or the token

In the discussion below, the income tax classification of coins and tokens in the hands of $A$ Co and Person $B$ will be analysed from a Danish and Swedish perspective.

\subsection{Classification of Coins}

\subsection{Coins as a Currency}

Both the terms cryptocurrency and coin - as well as their intended functions as alternatives to national currencies - give associations to official currencies like the US dollar or euro. Capital gains and losses from claims in official currencies are taxed under lex specialis rules in both Denmark and Sweden with favourable deduction rights compared to the general taxation rules for assets held for capital investment and speculative

\section{Notes}

27 DK: Corporate Income Tax Act, ss 1, 2 and 8(2) and DK: Taxation at Source Act, s. 1 and 2. SE: Income Tax Act (1999:1229), Ch. 3 for individual taxpayers and Ch. 6 in respect of corporate taxpayers.

28 J. Pedersen, in Skatteretten 1, 8d, 41 (Karnov Group 2018); S-O. Lodin, G. Lindencrona et al., in Inkomstskatt - en läro- och handbok i skatterätt Del 1, 17d, 39 (Studententlitteratur AB 2019).

29 SE: Ch. 65 s. 10 of the Income Tax Act and DK: Corporate Income Tax Act, s. 17.

30 SE: Ch. 1 s. 3 of the Income Tax Act.

31 Compared to Danish income tax law, one unconventional feature of Swedish income tax law is that it combines the progressive tax rate on employment income with a flat tax of $30 \%$ on capital income. However, as the rules for calculating capital gains and deduction rights diverge between different sections of capital income, such as shares or real estate, the net taxation may vary between different types of capital income, cf. G. Lindencrona, Unique Features in Swedish Tax Law, Stockholm Institute for Scandinavian Law, 167 (2007), SE: Ch. 44-55 and 65 of the Income Tax Act.

32 If a tax system defines income in a global way a country includes any item of income in the taxable income unless specifically excluded whereas an item of income is not taxable income unless specifically included in a specific schedule according to a scheduler tax system. For more on this respect, see R.S. Avi-Yonah, N. Sartori \& O. Marian, Global Perspectives on Income Taxation Law (Oxford University Press 2010).

33 However, in Sweden, the question will not be whether capital gains and losses from cryptocurrencies are tax exempt but rather what capital income category they will be classified as.

34 The example has been designed to include tax consequences for both companies and individuals, as well as both the issuance and transfer of cryptocurrencies. Due to space allowances, an important delimitation is that the example considers only domestic transactions - although transactions of cryptocurrencies are often transnational. 
purposes. ${ }^{35}$ Under lex specialis rules in the Danish Act on Taxation of Capital Gains and Losses on Claims and Debt, ${ }^{36}$ gains and losses from a claim on money fall within the scope under section 1(1) of the Act. ${ }^{37}$ In Sweden, gains and losses from claims in national and foreign currencies are taxable under the lex specialis rules in Chapter 48 of the Swedish Income Tax Act (ITA). ${ }^{38}$ An initial question in both jurisdictions is whether coins like Bitcoin could be considered official currencies for tax law purposes. As coins - for obvious reasons - cannot be seen as national currencies, the question in both Danish and Swedish tax law will be whether coins can be considered foreign currencies.

Although the term 'foreign currency' is used in both Danish and Swedish law, a clear definition of the term is lacking. In Denmark, there seems to be no existing case law on provisions including the criteria that define the term 'foreign currency' specifically. Nevertheless, after the introduction of cryptocurrencies, the Danish tax authorities have attempted to overcome this challenge. According to the Danish Tax Assessment Board, ${ }^{39}$ coins like Bitcoins, Bookcoins and Ethers cannot be regarded as official currencies for Danish tax purposes, as such coins are ${ }^{40}$ :

- not regulated by the actors on the global currency market;

- not subject to regulation by a central bank;

- not required to be redeemed. Although the meaning of this condition is unclear and not elaborated upon further, it may be understood as status of legal tender, which means that the debtor can settle debt in that currency and the creditor is obliged to accept that currency; and

- not affiliated with a state or currency area.

Although the administrative decisions consider specific coins, it is likely that none of the coins known today will be considered foreign currencies in Denmark based on similar arguments - even though the listed criteria do not seem to be cumulative. Both the meaning of the conditions and their legal basis remain unclear as none of the legal tax acts or case law seem to include the listed characteristics, and unfortunately neither the Danish Tax Assessment Board nor the Danish tax authorities have as of yet not made any references to the legal sources on which their positions have been based. Nonetheless, the characteristics of official currencies stated by the Danish Tax Assessment Board are not surprising if one takes into account the common understanding of official currencies. $^{41}$

In Sweden, the Supreme Administrative Court ${ }^{42}$ has in December 2018 given a judgment in a case concerning the sale of Bitcoins. Bitcoin was not considered as a foreign currency because:

- it does not have an issuer; and

- it is not a legal tender in any state. ${ }^{43}$

As for the latter criterion, only currencies issued by the national bank are considered legal payment methods in Sweden. ${ }^{44}$ This means that for a cryptocurrency to be considered a foreign currency, it must be issued and a legal payment method under the law of a state that Sweden recognizes. The ruling clarifies the earlier position taken by the Swedish Council for Advance Tax Rulings. ${ }^{45}$ The criteria are new and compared to the position of the Council they seem to be stricter as previous criteria of the Council did not include the criterion of a 'legal tender in any state', but required a foreign currency to (1) have an official issuer, (2) have a value based on a claim and (3) be a generally accepted payment method. ${ }^{46}$ In line with the criteria presented by the Supreme Administrative Court, coins with similar functions to Bitcoins (e.g. Litecoin) will not be considered foreign currencies in Sweden.

Comparing the positions of the Danish Tax Assessment Board and the Swedish Supreme Administrative Court, both require a foreign currency to be issued by someone. The Danish criteria seem to be stricter, as the issuer is required to be an internationally recognized institution. Swedish private law requires issuers of digital currencies not connected to an official institution or government to

\section{Notes}

35 In Sweden, capital losses from claims in foreign currencies are only deductible up to $70 \%$ under the wording of SE: Ch. 48 s. 23 of the Income Tax Act. However, in case law $\mathrm{R} \AA 2009$ ref. 33 this rule has been found to infringe on EU law and the position of the Swedish Tax Authority is that all losses are deductible in full, including claims in currencies from non-EU countries. SE: 22 Apr. 2009, RÅ 2009 ref. 33, dnr 131 346922-09/111.

36 Consolidated version of DK: Act on Taxation of Capital Gains and Losses on Claims and Debt 1283 of 25 Oct. 2016.

37 DK: Act on Taxation of Capital Gains and Losses on Claims and Debt also regulates the taxation of gains and losses on financial contracts within the scope of Ch. 6.

38 SE: Income Tax Act (1999:1229) (Inkomstskattelag).

39 The Danish Tax Assessment Board is the highest tax assessment body in Denmark. The body has 19 members: six are elected by the Parliament and 13 by the Minister of Taxation. One of its most important tasks is to issue advance binding rulings to taxpayers applying for such rulings.

40 Decisions of the Danish Tax Assessment Board published as SKM2014.226.SR (published 1 Apr. 2014) regarding Bitcoins SKM2017.520.SR (published 31 Aug. 2017) regarding Bookcoins and SKM2018.130.SR (published 3 Apr. 2018) regarding Ethers.

41 In J. Enyi, Er bitcoin penge? Erhvervsjuridisk tidsskrift 127 (2018) discusses the definition of money according to various different theories and finds that Bitcoin, as it is today, cannot be defined as money.

42 The supreme general administrative court in Sweden, which considers determinations on appeal from any of the four Swedish administrative courts of appeal.

43 SE: HFD 2018 ref. 72.

44 SE: Ch. 9 s. 14 of the Constitution of Sweden (1975:152), SE: Ch. 5 s. 1 of the Sveriges Riksbank Act (1988:1385).

45 An agency under the Department of Finance that delivers binding preliminary rulings within tax law. Preliminary rulings can be appealed to the Supreme Administrative Court. No special permission to appeal is required.

46 SE: Skatterättsnämnden, Avyttring av bitcoin 78-17/D, 18 Apr. 2018, where these critera were laid out by the Council for Advance Tax Rulings. 
seek special permission from the financial supervisory authority of Sweden. ${ }^{47}$ Apart from this, the remaining listed requirements of the Danish and Swedish tax authorities diverge. ${ }^{48}$

Considering the international tax literature, it seems to be the general opinion that the conditions usually associated with money in a legal context are that (1) the currency must have the status of a legal tender, which means that the debtor can settle debt in that currency and the creditor is obliged to accept that currency, (2) the currency must be regulated by a central bank and (3) the currency must also exist in physical form. ${ }^{49}$

Further, when considering economic theory, money is characterized as (1) a medium of exchange, i.e. an intermediary in trade to avoid the inconveniences of a barter system, (2) storage of value, i.e. money can be saved and retrieved in the future and (3) a common measure of value, i.e. acts as a standard numerical unit for the measurement of value and costs of goods, services, assets and liabilities. ${ }^{50}$ These economical characteristics can hardly be regarded as fulfilled in respect of the coins known today. Even though some coins, for example Bitcoins, are accepted among some businesses and individuals as a means of payment, the level of acceptance is relatively low. In relation to the second characteristic, although so-called 'stable coins', which typically refer to coins tied to the value of an official currency (e.g. US dollar) have emerged, it can be argued that the value of coins tends to be extremely volatile, which makes coins a highly uncertain form of storing values. Finally, as the coins known today are not likely to meet the first and/or second economic characteristic of money, the last characteristic is likely not to be considered fulfilled. Consequently, it seems to be in accordance with the underlying economic substance when the Danish and Swedish tax authorities do not classify Bitcoins and similar coins as foreign currencies. ${ }^{51}$

Even if a coin would - hypothetically - qualify as foreign currency, it is submitted that it would not be taxed under the lex specialis rules in either of the jurisdictions already because it is not a claim in foreign currency. For a coin to be considered a claim for Swedish tax purposes, there must be a counterparty, i.e. an originator to whom the claim can be directed. As coins are not issued by a specific party but instead created by a network consisting of users and then stored in a file online or on the investor's computer, there is no originator to direct the claim towards. ${ }^{52}$ According to Danish preparatory works, a claim requires that an owner has 'a legal claim for money that can be taken to the courts'. ${ }^{53}$ For example the placing of Bitcoins in a Bitcoin wallet does not give an owner this right. Therefore, this condition is not fulfilled. Finally, the Danish tax authorities only explicitly considered whether coins are official currencies and not the somewhat wider definition claim in 'money'. However, it seems unlikely that coins should be considered money based on the above analysis.

\subsubsection{Coins as a Personal Asset}

In the analysis, it has been found that the coins known today cannot be classified as claims in foreign currency under the lex specialis rules in Danish and Swedish tax law. Both laws include lex specialis rules on assets similar to shares or securities. However, already because coins do not represent an ownership in a company and the change in value is not connected to an economic activity or development of an issuing company, they will not be considered assets similar to a share or security from a Danish and Swedish perspective. ${ }^{54}$ Instead, coins will fall under the scope of the lex generalis rules on capital assets in both Denmark and Sweden.

In a Danish context, this leads to the applicability of the Danish State Tax Act ${ }^{55}$ which dates back to the beginning of the twentieth century. The starting point of section 5 of the Danish State Tax Act is that capital gains or losses from sales of personal property are tax exempt and non-deductible. Exemptions may apply, as

\section{Notes}

SE: Ch. 2 s. 1-2 of the Electronic Money Act (2011:755).

48 The Swedish criteria of a currency having to be a legal tender in a state and the Danish criteria not having to be redeemed are interesting in relation to case law concerning the free movement of capital from the European Court of Justice (ECJ). In Thompson (C-7/78) the ECJ has expressed that (gold) coins are to be considered currencies on the money markets of those Member States which permit dealings in these coins, regardless of whether doubts may be entertained on whether they are to be regarded as means of legal payment. Instead, the determining factor seems to be whether the Member State permits trade in these coins on the national money markets. Swedish case law seems to follow the ECJ criteria in this regard. Looking at the Danish criteria, it seems like coins do not have to be redeemed to be considered a currency according to the ECJ, i.e. it is sufficient that it has the potential to be used as means of payment. Although the case focuses on a different goal compared to national classification, it is worth noting since stricter national criteria can potentially be problematic in relation to the free movement of capital within the EU; UK: ECJ, 23 Nov. 1978, Case C-7/78, Thompson, ECLI:EU: C:1978:209, para. 27

49 See e.g. European Central Bank, Virtual Currency Schemes: A Further Analysis 24 (European Central Bank, Feb. 2015), or A. Bal, Ch. 14: How to Tax Bitcoin? in Handbook of Digital Currency 270 (D.L.K. Chuen ed., Elsevier 2015).

50 See e.g. W.S. Jevons, Money and the Mechanism of Exchange 14-16 (D. Appleton and Co 1896); European Central Bank, supra n. 49 , at 23.

51 Although the principle of substance over form has influenced both Swedish and Danish income taxation, the scope seems to be somewhat wider in Denmark. Ch. 'verklig innebörd', A. Hultqvist Rättshandlingars verkliga innebörd, Skattenytt, 696-703 (2007) and 'realitetsgrundsætningen' in Pedersen, supra n. 28, at 136-38.

52 Cf. E. Elgebrant, Kryptovalutor - Särskild rättsverkan vid innehav av bitcoins och andra liknande betalningsmedel, 41-44 (Wolters Kluwer 2016), M. Mellqvist \& I. Persson, Fordran E Skuld, 10d, $20 \mathrm{ff}$ (Iustus 2015).

53 DK: Point 4 in circular no. 134 of 29 July 1992 cited in the in the preparatory remarks for regulation, no. 439 of 10 June 1997 (L 194) as well as the preparatory remarks to s. 1 in regulation, no. 439 of 10 June 1997 (L 194).

54 The question of what is to be considered an asset similar to a share for Swedish and Danish tax law purposes is analysed in s. 3.4.

55 This applies only to gains and losses from the sale of the actual coins and not margin transaction on crypto-exchanges which are generally taxed as financial contracts in Ch. 6 of the Danish Act on Taxation of Capital Gains and Losses on Claims and Debt. 
capital gains and losses from the sale of personal property acquired in the course of a taxpayer's habitual trade or with a speculative purpose are taxable and deductible. With respect to coins and their often high volatility and somewhat limited applicability as a means of payment, the exemption of speculative purposes is crucial in regards to the investor.

The wording of section 5 of the Danish State Tax Act is silent on what should be regarded a speculative purpose. Nor do the preparatory remarks provide any guidelines to the interpretation of the term 'speculative purpose'. However, given the age of the provision, a vast amount of case law exists - though not in relation to coins. ${ }^{56}$ According to the case law, the important point in time to make an assessment on whether a coin has been purchased with a speculative purpose is the time of acquisition. ${ }^{57}$ It also underscores the significance of determining whether the taxpayer had the intention of selling the coin with a gain. However, the speculative purpose does not have to be the sole purpose or even the primary purpose of acquiring a coin. It is in fact sufficient that the potential of a gain from the sale of a coin was not insignificant at the time of acquisition. ${ }^{58}$

It should be of little surprise that challenges in respect to determining the 'intention of the taxpayer' arise. By acknowledging this, the courts have allowed to base the assessment on more objective matters surrounding the time of acquisition as well as the time after acquisition until the asset is sold. Summarizing the case law (unrelated to coins) and administrative practice from the Danish Tax Assessment Board in regard to Bitcoins and Ethers, the assessment of whether coins have been acquired for speculative purposes should take the following elements into account when determining if a coin similar to Bitcoin and Ethers has been acquired for speculative purposes ${ }^{59}$ :
- whether the price of the specific coin has been volatile and/or increasing on average;

- whether the specific coin has limited practical applications;

- whether the specific coin has no or limited personal attachment tied to it;

- whether the specific coin can be easily bought and sold; and

- whether the coin and realized gains and losses from the sale of the coin has been subject to extensive media coverage. Here it could be argued to apply to cryptocurrencies in general as they have been covered extensively by the Danish media - hence, all coins will likely be subject to this.

Consequently, when determining whether coins are acquired for speculative purposes, it is not possible to draw a clear line. Instead, the taxation should be based on a case-by-case assessment that takes the outlined elements into account when weighing the facts and circumstances of the individual coins and taxpayers. Nevertheless, according to the Danish tax authorities, the elements result in a rebuttable presumption of coins similar to Bitcoins and Ethers being acquired with speculative purposes. ${ }^{60}$

If a coin is considered to have been acquired by an investor for speculative purposes, the profits are taxable under section 4 of the Danish State Tax Act. For individuals, such income shall be taxed as personal income, i.e. at an effective maximum tax rate of approximately $53 \%$. Losses have a limited effective deduction value of up to approximately $27 \% .{ }^{61}$ Hence, taxation of gains and losses realized from the sale of coins is asymmetric for the individual taxpayer. However, this asymmetry does not apply to corporate taxpayers where taxable gains and deductible losses realized by companies selling coins are taxed at the corporate tax rate, i.e. $22 \%$ - assuming that this is a part of the business of the company and that the losses are incurred in acquiring, maintaining or securing taxable

\section{Notes}

56 Case law interpreting the term 'speculative purpose' has been declining with the adoption of several lex specialis on taxation of capital gains.

57 This was also stated in s. 8D of the guidelines issued by the Finance Ministry (31 Dec. 1912) in respect of the application of the Danish State tax act.

58 Administrative practice of the Danish Tax Assessment Board on coins: Decisions published as SKM2018.104.SR (published 9 Mar. 2018) SKM2018.130.SR (published 3 Apr. 2018) and SKM2018.288.SR (published 18 June 2018) where the Danish Tax Assessment Board stated that according to case law the speculative purpose is not required to be the sole reason justifying the acquisition - it is not even a condition that speculation is the main subject, it is generally sufficient that the speculative purpose is not insignificant upon acquisition. Similar is stated in Supreme Court cases DK: UfR 1980.24, H, DK: UfR 1985.749 H, DK: UfR 1986.308 H and DK: UfR 1986.639 $\mathrm{H}$ though all in respect of other personal properties. The latter stating that the mere possibility of selling condominiums was important in deciding whether a property (suitable for parcellation) for sale was acquired for speculative purposes.

59 See e.g. the Supreme Court cases DK: UfR 1974.353 H and DK: UfR $1980.121 \mathrm{H}$ where the court in its reasoning for its decision emphasized the (un)realized practical applications. For example in the latter a taxpayer had purchased a house for private housing; however, due to various circumstances the taxpayer never moved in and when the buildings burned down, the taxpayer did not rebuild the buildings, i.e. the taxpayer never realized the practical applications. Further, DK: UfR 1950.120 H, DK: UfR $1952.701 \mathrm{H}$, DK: UfR $1979.979 \mathrm{H}$, where the court emphasized that the taxpayers had/had not had an expectation that the acquired property would increase in price in the future. In addition, in DK: UfR 1921.113 H, DK: UfR 1950.120 H and DK: UfR 1976.474 H, the court in its reason for decision emphasized that the taxpayers had realized a significant gain. In DK: UfR 1921.113 and in DK: UfR $1979.979 \mathrm{H}$, the duration of ownership was relatively short which according to the court indicated a speculative purpose. In DK: UfR 1921.113 H and DK: UfR 1979.979 H, the acquisition price relative to the taxpayers' income in general was emphasized by the court.

60 Guidelines of the Danish tax authorities (Juridisk vejledning) s. C.C.2.1.3.3.3. According to the Danish Tax Assessment Board in its decision published 13 Feb. 2019 as SKM 2019.78.SR, this presumption was rebutted by a taxpayer who had received two Bitcoins together with two physical certificates and two silver coins representing the Bitcoin with the Bitcoin logo as a Christmas gift from her boyfriend in 2013. The facts could be attested by the boyfriend, family members present on Christmas Eve as well as pictures of the two certificates and silver coins. In addition, an e-mail had also been submitted to the tax authorities, which documented the purchase of the two Bitcoins by the boyfriend on 13 Dec. 2013. The taxpayer had at this time not heard of Bitcoins at all.). On this basis the Danish Tax Assessment Board found that the Bitcoins could not be seen as to have a speculative purpose and hence any gains and losses realized from the sale of the Bitcoins would be tax exempt.

61 DK: s. 3(2) of the Personal Income Tax Act. 
income. ${ }^{62}$ Gains and losses should as a starting point be calculated based on the sales price of a coin less the acquisition price of a coin, i.e. a coin-for-coin principle apply. In case only part of the coins owned by a taxpayer are sold and the specific coins which are sold cannot credibly be identified, the first in, first out principle should be applied. ${ }^{63}$

From a Swedish perspective, coins will generally fall under the income category of other assets in Chapter 52 of the ITA. Contrary to Danish tax law, the starting point is that the assets will be seen as held for capital investment purposes. Capital gains are taxed in full and calculated as income from sale minus an average of the purchase price. ${ }^{64}$ An exception applies if the asset is held for personal use. Assets in this category are taxable only on capital gains exceeding SEK 50,000 (approximately EUR 5,000) and the deductible expenditure cost may be calculated by $25 \%$ of the remuneration reduced by sales provision and other expenses related to the sale.

When categorizing an asset into one of the two categories, a main purpose assessment should be applied based on whether the actual use of the asset has been for personal use or capital investment purposes. The assessment should then focus on whether the capital investment component of the coin dominates the personal use component. ${ }^{65}$ For example assets held for investment purposes can be precious metals, diamonds and collectors' items not displayed in the personal residence. ${ }^{66}$ Correspondingly, assets held for personal use include personal household effects and items such as regular cars, ornaments, jewellery and collectors' items. From case law, it can be deduced that the assessment should be based on the time of purchase to the sale of the asset. ${ }^{67}$ Further, the intended use of the asset at the point of creation can form a presumption on the asset being held for personal use or for investment purposes. ${ }^{68}$

From a case law perspective, the Swedish Supreme Administrative Court has stated that neither the circumstance that a Bitcoin is used as a payment method nor any other circumstance can make it qualify as a personal asset. ${ }^{69}$ In other words, the capital investment component of Bitcoin is too predominant for it to be considered a personal asset. Even if Bitcoin was part of, for example, a collection of cryptocurrencies, it would not be seen as a personal asset. Therefore, Bitcoin and similar coins will be taxed as assets held for capital investment purposes in Chapter 52 of the ITA. Capital gains are taxed in full as income of capital with a separate tax rate of $30 \%$ for individual taxpayers; deductions of losses for individuals can be made by a maximum of $70 \%$ against capital income; and companies are taxed on a corporate tax rate of $20.6 \%$ for gains and capital losses that are fully deductible.

In summary, the classification of coins known today from a Danish and Swedish tax perspective, should likely not be regarded as official currencies. Under both tax systems, there is a strong presumption that coins are acquired for investment or speculative purposes. In the example, the result will be that $A \mathrm{Co}_{\mathrm{O}}$ is taxed at a rate of $22 \%$ in Denmark and $20.6 \%$ in Sweden on capital gains. Losses may be fully deducted in both countries assuming that losses are incurred in acquiring, maintaining or securing taxable income. In Sweden, Person $B$ is taxed at a rate of $30 \%$ on capital gains and $70 \%$ of the losses against other capital gains, whereas in Denmark, Person $B$ is taxed at an effective maximum tax rate of $53 \%$ on capital gains while losses are deductible by approximately $27 \%$. Capital gains and losses on coins are taxable and deductible in both countries. However, the taxation for individual taxpayers is asymmetric as the gains are taxed at a higher rate than the corresponding deduction of losses.

\subsection{Classification of Utility Tokens}

Cryptocurrencies with features different from coins may also be classified and taxed differently depending on the specific attributes of each cryptocurrency. ${ }^{70}$ As previously

\section{Notes}

62 DK: s. 17(1) of the Corporate Income Tax Act. However, the Danish Tax Assessment Board in a Danish a decision back in 2014 stated that the use of Bitcoin in the course of business was related to the owner's private interest instead of the company.

63 See e.g. the decisions of the Danish Tax Assessment Board in its decision on Bitcoins and Ethers published 8 Feb. 2019 as SKM2019.67.SR, and similarly decisions of the Danish Tax Assessment Board published as SKM2018.104.SR (published 9 Mar. 2018), SKM2018.130.SR (published 3 Apr. 2018) and SKM2018.288.SR (published 18 June 2018)

64 SE: Ch. 52 s. 3 of the Income Tax Act.

65 For assets on the borderline between the two categories, e.g. collectors' items, a case-by-case assessment also considering subjective elements should be conducted. This specific assessment should not apply to the coins used today, since they are typically stored on a computer and not displayed on the personal property, SE: prop: 1989/ 90:110, 475 .

66 The fact that an asset is valuable does not automatically qualify it as held for investment purposes, SE: Prop: 1989/90:110, 474 f and prop. 1999/2000:2 part 2, 606.

67 SE: RÅ 2009 ref 77. Where a valuable painting which was sold at an auction directly after an inheritance transfer was considered an asset for personal use due to the deceased for several generations back having held the painting for personal use.

68 SE: RA 2005 ref. 4. Playing rights in a golf club were to be presumed to be held for personal use before the actual sale, since the assets were created mainly to regulate the playing rights on the field.

69 SE: HFD 2018 ref. 72. Where Bitcoin was not considered as a foreign currency but an asset held for capital investment purposes.

70 In line with this principle, the Danish Tax Assessment Board classified the cryptocurrency Bookcoins of which the owner also owns an equivalent amount of silver as a financial contract, more specifically a 'structured note', i.e. a note which value follows the value of an underlying asset - in this case silver. Whether you agree with the classification or not, the decision illustrates that the Danish Tax Assessment Board does not necessarily classify all cryptocurrencies similarly. For a critical analysis of the classification of Bookcoin as a structured note, see (in Danish) L. Fjord Kjærsgaard \& K. Dyppel Weber, Skattemassig behandling af virtuelle valuta, Tidsskrift for Skatter og 
stated, utility tokens are characterized by not giving any promised or perceived return on investment. Instead, they are constructed to function as a payment method within a network. Leaving the technical construction aside, the difference between coins and utility tokens is mainly the purpose for which they are created, i.e. as a general payment method versus a payment method within a specific network. This implies that whereas the value of coins is based on market supply and demand of the coin itself, the value of a utility token is based on the value of the goods or services within the network of the issuing company.

There are no regulations or case law in Denmark and Sweden on how utility tokens should be treated for income tax purposes. Compared to coins, utility tokens are even less likely to be considered an official currency since they can only be used as a means of payment within a specific network. The main question in both Denmark and Sweden seems to be whether utility tokens should be considered a personal asset or an asset held for capital investment and speculative purposes. Even though utility tokens do not give any perceived or promised return, investments in utility tokens are today often speculative, which makes the value of the token volatile. ${ }^{71}$ Combined with the similarities in the construction and function between utility tokens and coins, most utility tokens will likely be considered a taxable asset held for investment and speculative purposes.

In the example, this would mean capital gains and losses from utility tokens in the hands of $A$ Co and Person $B$ will be taxed equally to coins. Utility tokens will typically be considered as assets held for investment purposes in Sweden and correspondingly as acquired with a speculative purpose in Denmark. For $A$ Co, this means that any gains realized by issuing utility tokens as part of financing a business idea is taxable in full. Expenses incurred in acquiring, securing or maintaining the income generated from the issuance of the token will generally be deductible. $^{72}$ From a tax perspective, this makes ICOs of utility tokens a less beneficial way of raising funds for start-ups in Denmark and Sweden compared to, taxexempt issuance of shares, for instance, despite the many benefits in terms of cost efficiency.

The purpose and context of the transaction of a utility token can affect the assessment. If $A$ Co issues a utility token that represents a right to buy books from a company while the price of the utility token is stable and less suitable for investment and speculation purposes, the utility token could potentially be considered a personal asset in the hands of the investor. As stated above in section 3.3., this classification will imply that any gains and losses will be non-taxable and non-deductible under Danish tax law. Whereas, Swedish tax law will impose tax on capital gains exceeding SEK 50,000 (approximately EUR 5,000) and allow for a deduction of expenditure cost calculated as $25 \%$ of the sales price reduced by sales provision and other sales-related expenses. Another example of when a utility token is closer to being a personal asset is if $A$ Co as a charity organization that issues a token that can be used to acquire a pink ribbon charity bow. In such ICOs, the purpose of the issuing charity organization as well as the characteristics of the asset (the pink ribbon charity bow) will likely imply that the utility token is classified as a personal asset not acquired for investment and speculative purposes. A final example is if $A$ Co - as part of its marketing strategy - issues and donates a token that represents a playing right to a game operated by $A$ Co to Person $B$ for a charity purpose. In this case, it could be argued that the utility token is a deductible marketing cost for $A$ Co. Person $B$ is more likely to be seen as having held the utility token for personal use.

In summary, most utility tokens today will likely be taxed the same as coins in both the hands of the issuer and the investor as they will be acquired for investment and speculative purposes. However, some utility tokens could potentially be taxed as a personal asset in the hands of the investor - depending on the price fluctuation of the specific token, the purpose of the specific issuing company, the rights or type of goods connected to the utility token and the purpose of the intended use. Nonetheless, due to the lack of regulation and case law, taxation on capital gains and losses from the sale of utility tokens is uncertain under Danish as well as Swedish tax law.

\subsection{Classification of Security Tokens}

\subsection{Security Tokens with Share-Like Features}

As described in section 2. security tokens have varying constructions with features similar to shares and/or bonds. There are no Danish nor Swedish regulations or publicly available case law on the classification of security tokens for income tax purposes. Looking at security tokens with share-like features, for example, including voting or profit participating rights within the issuing company, an initial question will be if they may be taxed under the lex specialis rules of shares and similar assets for Swedish or Danish income tax purposes.

For Danish tax purposes, the taxation of gains and losses from the sale of shares follows the Danish Act on

\section{Notes}

Afgifter 1 (2018). Similarly, the position of the Swedish tax authority is that 'Onecoin' is not a cryptocurrency, but a pyramid game and should be taxed as a lottery. Skatteverket, Kryptovalutor, https://www.skatteverket.se/privat/skatter/vardepapper/andratillgangar/kryptovalutor.4.15532c7b1442f256bae11b60.html (accessed 2 Mar. 2019).

71 Adkinsson, supra n. 25.

72 In Sweden, this follows from SE: Ch. 16 s. 1 of the Income Tax Act, and in Denmark, this follows from DK: s. 6a of the State Tax Act. 
Taxation of Capital Gains from the Sale of Shares, which according to section 1 covers, among other things, shares and similar securities. However, neither the provision itself nor its preparatory remarks elaborate on what should be considered similar securities.

According to case law, three characteristics of 'similar securities' may be deduced. First, a security is required to be transferable from the investor; second, a security should represent an ownership in a company which confers ownership to a proportion of company assets as well as liquidation proceeds; and third, a company must be considered a company similar to a Danish limited liability company, i.e. aktieselskab (A/S) or anpartselskab (ApS). ${ }^{73}$ For company law purposes, it seems questionable whether an owner of sharelike tokens issued by a Danish limited liability company should be considered to constitute such ownership as this would likely be reserved for owners of the share capital of a company. ${ }^{74}$ Further, the issuance of shares by a Danish limited liability company that increases its capital share must be registered for corporate law purposes if the shares should be considered within the scope of the Danish Act on Taxation of Capital Gains from the Sale of Shares. In other words, if an increase in share capital of a Danish limited liability company is not registered, the shares cannot be considered securities similar to shares from a Danish tax perspective. ${ }^{75}$ Although it is uncertain whether this requirement also applies to securities similar to shares issued by a Danish limited liability company that also has issued shares, it seems unlikely that share-like tokens issued by a Danish limited liability company that also have issued shares will fall within the scope of the Danish Act on Taxation of Capital Gains from the Sale of Shares. However, it cannot be precluded that specific share-like tokens theoretically may be considered securities similar to shares.

Another option is for share-like tokens to be considered so-called yield contracts (DK: Udbyttekontrakter), which is a contract providing a right that results in certain income for a certain period of time as long as the contract is still in force. ${ }^{76}$ An example of a yield contract in case law is a special permit-license that a truck driver needs to drive in specific areas. If the truck driver utilizes the permitlicense, this will result in certain income. ${ }^{77}$

Under section 40(6) of the Danish Depreciation Act, capital gains and losses on yield contracts are taxable and if yield contracts are used in the course of business of the investor, it is possible to deduct depreciations on the yield contracts. Even though the phenomenon of yield contracts is almost eighty years old, the scope of the term is uncertain. ${ }^{78}$ According to case law, it is not only a contract providing the right to a certain income which could be classified as a yield contract but also a contract providing the right to an opportunity for a certain income strictly connected to the right provided under the contract. ${ }^{79}$ As share-like tokens typically give the investor the right to profit participation, it could be argued that they may be classified as yield contracts. A counter argument could be that in the case of share-like tokens, the connection between the right to income and the realization of such income is too vague. This argument would be based on the uncertainty of whether an investor actually will realize income as well as the fact that an investor typically has little or no influence on whether the issuing company realizes a profit. Finally, only existing yield contracts fall within the scope of the provision, i.e. a situation where an investor is involved in the creation of a yield contract would fall outside the scope of the term. ${ }^{80}$ In respect of share-like tokens, an investor should likely not be considered a co-creator of the tokens.

Regardless of whether share-like tokens are classified as yield contracts or assets similar to coins and utility tokens, the taxation of a private investor's gains and losses from the sale of share-like tokens is similar to the taxation of coins described above. It seems likely that share-like tokens typically will be considered to be acquired for speculative purposes. Further, any return on the invested capital distributed from the issuing company will be taxable under section 4 of the Danish State Tax Act and hence taxed at a maximum effective tax rate of $53 \%$.

\section{Notes}

73 In DK: TfS $2004.482 \mathrm{H}$, the Supreme Court stated that the membership of a guarantee association (Fondsbgrsvekselerernes Garantiforening) did not represent an ownership in the company which conferred to a legal right to a portion of the company's liquidation proceeds and hence the membership was not considered securities similar to shares. In DK: TfS 2001, $124 \varnothing$, the Danish Eastern High Court found that the membership of a mutual insurance association did not represent securities similar to shares as the membership according to the Article of Association was not transferable. Further, did they not represent an ownership in the company, which conferred to a legal right to a portion of the company's liquidation proceeds. In DK: LSRM 1968.6, the National Tax Tribunal stated that shares in a Finnish company were considered sufficiently similar to the Danish term of shares.

74 For corporate law purposes the business authorities stated in Report 1498 of Nov. 2008 in connection with the update of the Danish Corporate Act that the significant possibilities for determining financial instruments (shares, bonds etc.) should not be hindered in terms of the restrictions in the agreement and the arrangement between the company and the investors, see at 163 . However, as noted by Kaaland Dell'Erba, ICO promoters and their developers are not forced to sacrifice their equity in the project in exchange for the funds they raised. Kaal \& Dell'Erba, supra n. 17, at 11.

75 In DK: TfS 1988.550 LSR, the Danish Tax Tribunal found an increase in the share capital which was not registered could not (independent of the reasons for not registering the share capital) be considered shares or similar securities. See similarly DK: TfS 1984.189øLD and DK: TfS 1996.603 VLD.

76 The Danish Finance Minister in connection with the original provision in the previous Tax Assessment Act and the applicable s. 40 of the Danish Depreciation Act. See Retstidende 1939/40 question 1928. See similarly the Ministry of Taxation's Guidelines 97 of 26 June 1995, s. 2(3).

77 DK: LSRM 1982, 150.

78 C. Hedegaard Eriksen, Beskatning af immaterielle aktiver 76-82 (Jurist- og Økonomforbundets Forlag 2007).

79 See e.g. DK: TfS 1998,731 H, LSRM 1982, 150; DK: TfS 2002, $386 \varnothing$.

80 See e.g. DK: TfS 2002, $158 \varnothing \mathrm{LD}$ 
In respect of a Danish limited liability company issuing share-like tokens, the general rule is that a realized income from the sale of tokens in the course of business will be taxable for a Danish token issuer under section 4 , pursuant to section 5 of the Danish State Tax Act. However, given the similarities with shares, it can be questioned whether funds raised by issuing share-like tokens under an ICO may be classified as a tax-exempt increase in the share-capital of the issuing company under section 13(1) no. 1 of the Danish Corporate Income Tax Act. Considering the wording of this provision, a requirement is that capital is received by a company upon issuing of shares or by increasing its share capital for corporate law purposes. Under Danish case law, this exemption to taxation of funds raised may not be applied by way of an analogous application or a wide interpretation. ${ }^{81}$ On this basis, it seems unlikely that funds raised by a Danish limited liability company by means of issuing share-like tokens will be tax-exempt, as it will most likely not be possible for corporate law purposes to register this as an increase of share capital for corporate law purposes. ${ }^{82}$

From a Swedish perspective, an initial question is whether a share-like token may be classified as a share or security (SE: delägarrätt) under the lex specialis rules in Chapter 48 of the ITA. Assets that should be classified as shares or securities are specified in Chapter 48:3 of the ITA by an extensive definitions article, which includes shares, share-like financial instruments and other assets of similar construction and function. For a security token, the assessment should be based on whether it may be seen as an asset of similar construction and function. According to the preparatory works, analogous application of the rules on assets of similar construction and function should be restrictive. In principle, it would require the different components of the share-like token to be identical to a share. ${ }^{83}$ In Swedish case law, assets based on, for instance, a commodity index and not on an actual share value have not been considered of similar construction or function. ${ }^{84}$ The preparatory works specify that assets where the return on investment is connected to capital gains or dividends from the issuing company, or where the change in value is similar to shares, shall fall within the scope of the rule. ${ }^{85}$ In connection, Bitcoin has not been considered an asset similar to a share or security because the change in value is not connected to an economic activity or development of an issuing company. ${ }^{86}$

Compared to Bitcoin, security tokens can be issued by a company via an ICO. It could also be argued that value change is connected to the economic activity and development of the issuing company, if the token grants, for example, profit participating rights. Nonetheless, it can be questioned whether it is possible for a share-like token to have components identical to a share already by looking at the technical construction of the token. Considering this and the restrictive analogical application of the rule, it seems likely that in practice most tokens with share-like features will not fall within the scope of Chapter 48 of the ITA.

Instead, security tokens with share-like features will likely be considered assets held for capital investment purposes. In the hands of an investor, capital gains and losses will therefore be taxed similarly to coins. However, there is a hypothetical possibility that some tokens may fall under Chapter 48 of the ITA if (1) a taxable juridical person issues the token, (2) the return depends on the issuing company's financial development and (3) the price of the token being similar to that of a share.

Similarly, the issuing company should generally be taxed for capital gains and losses relating to the transfer of security tokens - unless the tokens are considered a taxexempt increase of share capital. Increase of share capital is as a main rule tax-exempt as it does not fall under any income category. There is no definition of the term in Swedish tax law. Rather, case law and legal doctrine are guiding for the taxation. Similar to Danish regulations, a general requirement should be that the increase of share capital is registered for corporate law purposes at the Swedish Company Registration Office. ${ }^{87}$ For the issuance of a token via an ICO to be considered an increase of share capital, an analogical application of the rules would thus be required where both the specific token would have to qualify as a share and the ICO would have to fulfil the procedural registration requirements for corporate law purposes. Although it is theoretically possible for a security token with share-like features to be seen as an increase of share capital, this will likely not be the case for most tokens.

\section{Notes}

81 The Danish Tax Assessment Board stated in SKM 2014.780.SR that in a planned aggregation of two heating plants the deposit of shares of the newly established company could not be tax-exempt following an analogous application of the Corporate Tax Act s. 13(1), no. 1.

82 There has previously been an uncertainty in administrative practice whether a subsidy without share issue in a foreign (joint taxed) subsidiary would be subject to tax. However, this was generally clarified by the Danish Supreme Court in DK: SKM 2009706 H. The Danish Supreme Court found that a transfer of capital to a Polish company without a share issue (in an international joint taxation) could not be tax-exempt according to DK: Corporate Tax Act, s. 13(1), no. 1, but was taxable under DK: State Tax Act, s. 4 .

83 SE: Prop. 1989/90:110, 722

84 SE: RA 2004 not. 97, where standardized electricity certificates were not considered of similar construction and function.

85 SE: Prop. 1989/90:110, 430 .

86 SE: HFD 2018 ref. 72.

87 SE: Cf. Companies Act (2005:551), Ch. 11 s. 1, where an increase in share capital by the issue of new shares is defined as new shares being subscribed in return for payment. Procedural requirements, such as registration at the Swedish Company Registration Office, are stated in Ch. 13 of the Companies Act. 
In summary, tokens with share-like features will generally be seen as assets held for capital investment and speculative purposes in both Sweden and Denmark. Even though it may theoretically be possible for share-like tokens to be seen as a tax-exempt increase of share capital, it is most unlikely that an analogical application of the current rules is possible. In the example, this means that both $A$ Co and Person $B$ are taxed on capital gains and from the sale of the share-like token in line with the taxation of coins.

\subsubsection{Security Tokens with Debt-Like Features}

Security tokens with debt-like features may include, for example, repayment and interest obligations. An initial question is if a payment from an investor to an issuer in the example should be seen as a loan or as a sale of an asset. Most security tokens will not have typical debt-like features as they in general only represent a potential future return on investment - e.g. a potential repayment if the company will make any profits in the future. The promised return is typically not connected to a specific point or event in time. In such case, the token should not be seen as a loan/debt but more similar to a letter of intent as an issuer has no legal obligation to return money paid to acquire the debt-like token. Consequently, security tokens with debt-like features will typically be taxed under the lex generalis rules on assets held for capital investment and speculative purposes in both Denmark and Sweden.

However, structuring possibilities of tokens issued via an ICO are, in principle, infinite. It is theoretically possible to structure a token as a debt with a specified repayment and return on investment in, for instance, an official currency or coins. In such case, the issuer (A Co) could be seen as taking a loan and the investor (Person $B$ ) as having a claim. Only the return on investment would then be taxable for the investor and deductible for the issuer. In the hands of the investor, a first question would then be if the token can be taxed as a lex specialis income, i.e. be classified as a claim in foreign currency in Sweden and a claim in money, likely also meaning foreign currency, in Denmark. ${ }^{88}$ Compared to coins, a debt-like token is more likely to be considered a claim, as there is an originator, i.e. an issuing company towards which a demand for payment can be directed. Further, the terms and conditions of an investment in a token via an ICO will be recorded in the ledger, which will make the transaction easy to prove in court. However, in line with the analysis on coins, any promised repayment in coins or tokens will not qualify as a claim in currency. Therefore, debt-like tokens will typically not be taxed under the lex specialis rules on claims in currencies in either jurisdiction but as assets held for investment and speculative purposes. Theoretically, one exception could be if the promised return on investment is in an official currency. In practice, however, this does generally not seem to be the case.

In summary, debt-like tokens will typically be seen as assets held for capital investment and speculative purposes in both Sweden and Denmark. The taxation will therefore typically be the same as for coins. Compared to utility tokens, the presumption of debt-like tokens being held for capital investment and speculative purposes will likely be even stronger as debt-like tokens are distinguished by promising some form of return on investment and cannot be of any personal use. The fact that a company issuing debt-like tokens as part of financing a business idea is taxed on any gains realized makes ICOs of security tokens a disadvantageous way of raising funds for start-ups in Denmark and Sweden from a tax perspective - despite the many benefits in terms of cost efficiency promised by the model.

\subsection{Classification of Asset Tokens}

Asset tokens represent the ownership of underlying individualized assets. In other words, an investor of an asset token acquires ownership of a specific identifiable asset. The Swedish Mapping, Cadastral and Land Registration Authority uses blockchain technology to transfer ownership of properties by digitizing physical documents that represent ownership of the real estate on the blockchain. Although this is not done via an ICO, it is an example of how asset tokens can be used. ${ }^{89}$

There is no tax regulation or case law in Sweden and Denmark concerning asset tokens. Considering that asset tokens represent individualized assets, it can be argued that tokenization of an asset should not influence the taxation of an asset as the underlying economic reality remains unchanged. In line with this, both the investor and the issuer should, in principle, be taxable for capital gains and losses in accordance with the tax treatment of the underlying asset.

From both a Danish and Swedish tax perspective, this approach would mean asset tokens could qualify for the lex specialis on capital gains and losses from, for example, real estates, debt, claims and shares. However, if these are not applicable, the lex generalis rule will apply. In such a case, the taxation of the issuer and investor will be similar to coins as described above.

From a Swedish tax perspective, the assessment of whether a disposal of an asset token representing an individualized asset has occurred could vary depending

\section{Notes}

88 SE: Ch. 48 s. 4 of the Income Tax Act.

89 The Land Registry in the blockchain, A development project with Lantmäteriet (The Swedish Mapping, cadastral and land registration authority), Telia Company, ChromaWay and Kairos Future (July 2016), http://ica-it.org/pdf/Blockchain_Landregistry_Report.pdf (accessed 6 Dec. 2018). 
on if the investor has received a right in rem for the specific asset. A disposal is defined in Chapter 44:3 of the ITA as a sale, exchange or similar transfer of assets. As the terms are not defined for tax purposes, guidance can be drawn from private law definitions. It is unclear to what extent private law terms should influence income tax law - and this has been widely discussed in legal literature. ${ }^{90}$ For income tax purposes, it seems like the assessment of whether a transfer of ownership has occurred mainly depends on whether the contractual ownership and the disposal rights of the asset have been transferred. ${ }^{91}$ In most cases, this would mean that a contractual owner, who can control the transaction of a specific coin or token, should declare income from the specific cryptocurrency. ${ }^{92}$ However, due to the unclear relationship between private law terms and tax law terms, it could also be argued that the assessment could be affected by whether the new owner of the coin or token has received a right in rem. In Sweden, rules on right in rem vary depending on the specific asset, which in particular could affect the assessment of asset tokens since asset tokens in theory can represent any type of underlying individualized asset. For example if the asset token represents an individualized movable property - for instance, a specific book - the book should typically have to be delivered or registered under the Sales and Registration of Movables Act (1845:50 s.1) to get a right of rem, i.e. it would likely not be sufficient to merely register the transfer in the blockchain. ${ }^{93}$ It should be underlined that the legal uncertainty in this regard is high, due to the unclear relationship between private and tax law definitions and the lack of regulations and case law on cryptocurrencies.

For a lex specialis rule to apply, the requirement for the underlying asset to be individualized seems to be strict in both Sweden and Denmark. For Swedish tax purposes, an asset token that represents a fungible physical asset which is not strictly individualized, for example, 'some silver coins', would likely not be seen as ownership of an asset but as a sort of claim. ${ }^{94}$ In case the claim is not in a foreign currency, such tokens would generally be taxed as assets held for capital investment purposes. However, if the underlying asset is, for instance, a share or an official currency, the lex specialis rules for shares and securities in Chapter 48 of the ITA could potentially be applicable.

From a Danish perspective, the individualization of the underlying asset has been discussed in a case considered by the Danish Tax Assessment Board concerning Bookcoins, which was a cryptocurrency where the owner of a Bookcoin owned a gram of silver typically stored at a deposit of the issuer but deliverable upon request. The value of a Bookcoin equalled a gram of silver and hence the cryptocurrency seems to be somewhat similar to an asset token. In this case, the Danish Tax Assessment Board stated that Bookcoins should be considered as a financial contract where the creditor is subject to the less favourable taxation regime in Chapter 6 of the Danish Act on Taxation of Capital Gains and Losses on Claims and Debt. More specifically, the Danish Tax Assessment Board stated that a Bookcoin should be considered a so-called structured note as the silver could not be considered as completely individualized - even though it was informed that the investor owned the silver outright and all transactions of Bookcoins were in allocated silver. A structured note is a legal claim on money and the value of this legal claim on money must be regulated in relation to price or similar on securities, goods or other assets. The classification of Bookcoin as a structured note has been criticized in tax literature, where the argument is that a legal claim on generic assets (silver) cannot be regarded as a legal claim on money - at least when the creditor does not have the option of repayment in money. ${ }^{95}$

Instead, Bookcoins and other tokens representing assets not strictly individualized, appear to be a right to get the underlying asset delivered on demand for Danish tax law purposes. The question then becomes whether such a right should be regarded as an autonomous asset for tax purposes or whether it should be regarded as a genuine (prepaid) purchase of the tokenized asset. It seems to follow from previous case law that such a right for tax purposes must be independently classified when the underlying asset is not a specific individualized asset and the contract is settled by net settlement. ${ }^{96}$ Net settlement refers to a situation where a transaction is settled by only

\section{Notes}

90 Hultqvist, supra n. 51, at 696-709

1 Elgebrant, supra n. 51, at $53 \mathrm{ff}$.

92 Ibid., at 54, where these arguments are presented regarding coins.

93 See e.g. SE: NJA 1997 at 660, where a movable property in form of a shipyard floating dock was not considered under right of rem because it had not been delivered to the buyer or registered in the Sales and Registration of Movables Act (1845:50 s. 1), even though the sale had been documented in an agreement between the parties and registered at an official registration office.

94 Cf. T. Håstad, Sakrätt avseende lös egendom, 6d, 24 (Norstedts Juridik AB, 2000), where it is concluded that a demand to obtain generic property based on the right of ownership is normally referred to as a claim.

95 For a critical analysis of the classification of Bookcoin as a structured note, see (in Danish) Fjord Kjærsgaard \& Dyppel Weber, supra n. 70. See e.g. G. Skouby et al., Kursgevinstloven - en lovkommentar 37 (Forlaget Magnus A/s. 2000), K. Joo Dyppel, Beskatning af aktielan og repo'er, 25 SR-skat 1 (2013); J. Bundgaard, Finansiel innovation som skatteretlig udfordring, mandatory convertibles \& reverse convertibles i dansk skatteret in Festskrift til Jan Pedersen, 43 (Djøf Forlag 2011).

96 See (in Danish) report from the Option Committee no. 1139 Beskatning af finansielle instrumenter 88 et seq. (June 1988), Fjord Kjærsgaard \& Dyppel Weber, supra n. 70, K. Joo Dyppel, Beskatning af finansielle kontrakter, Jurist- og Økonomiforbundets Forlag, 247 (2012), where it is stated that in such a case, the derivative is merely the contractual means of assuring the contract holder ownership of the underlying asset cf. H. Ketelsen i Aage Michelsen (edt.): Skatteret, 84-88 (1990), where the distinction between contracts taxed as individual assets versus the rules for the underlying asset is analysed. See C. Amby og Jørgen Egelund, De skattemassige regler vedrorende future, 
paying the difference between the agreed price and the market price - instead of delivering the asset and paying the agreed price. Conversely, it is assumed that an agreement on the delivery of an individualized asset can hardly be construed as anything other than an agreement for the purchase and sale of the underlying asset. ${ }^{97}$

In summary, asset tokens representing individualized underlying assets may be taxed in both Sweden and Denmark under the lex specialis rules applicable to the underlying asset, for example, real estate, shares or claims in official currencies. For Swedish tax purposes, relevant considerations include if the token is fully individualized and if so, if the investor has a right in rem for the underlying asset of the asset token. In Denmark, it will also be relevant to consider if the underlying asset is individualized as well as settled by actual delivery of the tokenized asset. $^{98}$ If the token has other features (e.g. net settlement), if the creditor has the option of payment in money, or if the tokenized asset is not completely individualized, the classification of asset tokens seems uncertain for Danish tax purposes and it will be relevant to assess whether the specific - and often disadvantageous - regulation of financial contracts apply.

\section{TAXATION OF CRYPTOCURRENCIES AND THE PRINCIPLE OF NEUTRALITY}

In connection with the growing impact of cryptocurrencies on the financial markets, the importance of reasonable taxation outcomes of coins and tokens also increases. Consequently, there should be an increased emphasis on neutrality arguments. As shown above, there is a wide range of cryptocurrencies with different features and functions. From the analysis, it has been submitted that there is a strong presumption that all coins and tokens will be classified as assets held for capital investment and speculative purposes in both Sweden and Denmark. As the construction and function of different cryptocurrencies diverge significantly, an interesting question is how the uniform classification relates to the principle of neutrality.

In both Danish and Swedish tax law, the principle of neutrality has significantly influenced the design of the capital taxation rules. ${ }^{99}$ However, there are different types of neutrality principles. In international tax literature, neutrality is often discussed in relation to prevention of international double taxation and theories about residence and source taxation. ${ }^{100}$ From a national Danish and Swedish tax perspective, the principle typically means neutrality between investment alternatives, ${ }^{101}$ and a higher tax burden naturally restricts the holding of a capital asset. ${ }^{102}$ In line with this neutrality principle, personal preferences, such as commercial reasons, should be the determining factors for the choice of investing in an asset. For instance in Sweden, this can be seen in capital gains being taxed at a flat rate of $30 \%$ as a main rule. Both jurisdictions have rules on the taxable amount and deduction rights for specific asset categories motivated by various fiscal and non-fiscal purposes. ${ }^{103}$ An example of which is the taxation of shares, which are granted more favourable deduction rights compared to the taxation of other assets held for capital investment and speculative purposes that fall within the scope of Chapter 52 of the ITA or the Danish State Taxation Act.

Many cryptocurrencies have features and functions similar to, for example, shares, securities or currencies. However, cryptocurrencies will by default generally fall outside the scope of the lex specialis rules - regardless of the similarities in the underlying economic substance of a coin and token. One important reason for which is the current tax law design not being adjusted to the underlying new technology of cryptocurrencies. In other words, a coin or token with the economic substance of a lex specialis category in Danish and Swedish tax law may already fall outside the scope because the listed criteria are not adjusted for the underlying technology. One example is security tokens with share-like

\section{Notes}

options og warrants. Revision \& Regnskab 10 (1987); K. Füchsel et al., Håndbog i finansielle instrumenter - funktion, regnskabsmassig behandling og skattemcessige aspekter 145 (Foreningen af Statsautoriserede Revisorers forlag 1991); P. Bach Jørgensen, Regnskab og Revision, 10 Revision \& Regnskab 10 (1988).

97 See also Option Committee, supra n. 96, at 109; Fjord Kjærsgaard \& Dyppel Weber, supra n. 70.

98 DK: Act on Taxation of Capital Gains from the Sale of Shares, DK: Act on Taxation of Capital Gains and Losses on Claims and Debt, DK: Act on Taxation of Capital Gains from the Sale of Real Estate and DK: Act on Depreciation.

99 For Swedish tax purposes, see M. Dahlberg, Kapitalinkomstbeskattningen: en översikt och probleminventering, Skattenytt 80-92 (2009), where an overview of the Swedish capital income taxation is given and the influence of the principle of neutrality is discussed. For Danish tax purposes, see e.g. the report of the Danish Ministry of Taxation on neutrality in the Danish tax system and specifically in the Hydro Carbon Tax Act, https://www.skm.dk/skattetal/analyser-og-rapporter/rapporter/2001/oktober/rapport-frakulbrinteskatteudvalget,-oktober-2001/3-neutrale-skatter-og-overnormal-profit (accessed 2 Mar. 2019), Pedersen, supra n. 28; S. Askholdt, Indledning og retskilder Skatteforvaltningens opbygning og opgaver in Larebog om indkomstskat 54, 17d (A. Michelsen et al. eds, Jurist- og Økonomforbundet 2007).

100 Capital Export Neutrality and Capital Import Neutrality was first discussed by Musgrave in 1963 and Richman in 1969. P. B. Richman, Taxation of Foreign Investment Income: An Economic Analysis (Johns Hopkins Press 1963) and P. B. Musgrave, United States Taxation of Foreign Investment Income: Issues and Arguments, International Tax Program (Harvard Law School, 1969). See also M. Berglund, Avräkningsmetoden 91 (Iustus Förlag 2013), where it is analysed how prevention of double taxation has been an important goal in international discussions on the principle of neutrality.

101 For Swedish tax purposes, see Dahlberg, supra n. 99. For Danish tax purposes, see e.g. DK: Ministry of Taxation, Report on Neutrality in the Danish Tax System and Specifically in the Hydro Carbon Tax Act, https://www.skm.dk/skattetal/analyser-og-rapporter/rapporter/2001/oktober/rapport-fra-kulbrinteskatteudvalget,-oktober-2001/3-neutrale-skatter-og-overnormal-profit (accessed 2 Mar. 2019) and Askholdt, supra n. 99.

102 M. Dahlberg, Ränta eller kapitalvinst 50 f (Iustus Förlag 2011).

103 For Swedish tax purposes, see Dahlberg, supra n. 99, where an overview of the Swedish capital income taxation is given and different motives behind the design of the rules are discussed. For Danish tax purposes, see Pedersen, supra n. 28, at 44-46, for a discussion of the various fiscal and non-fiscal purposes of Danish tax law. 
features, which will most likely not be classified as a share in neither jurisdiction - either because the formal requirements under corporate law cannot be fulfilled or because of the restrictive interpretation of what is to be considered an asset of similar construction or function to a share. In Sweden, issued tokens, in principle, must feature components identical to a share or security. It is unlikely that any token will fall under the scope due to the difference in construction of the underlying technology. Similarly, coins will not be taxed as a claim on currency simply because they cannot be considered a claim due to the decentralized construction of the technology. Differences in classifications due to the design of the underlying technology itself, and not due to actual differences in economic substance, can be argued to breach the principle of neutrality.

It can be argued that coins and tokens are risky investments because of the high price volatility and should not be taxed the same as, for instance, a share or security. Considering that many traditional volatile share-like instruments fall within the scope of the lex specialis rules in both Denmark and Sweden, it is submitted that price volatility should not be the sole reason for a divergent taxation of a token or coin in this case. However, the investment risk of cryptocurrencies is also connected to the market being unregulated. Looking at, for example, shares and bonds, there are neither regulatory frameworks sufficiently preventing fraud and misinformation nor are issuing tokens via an ICO typically regulated like the issuance of shares via an IPO. From a neutrality perspective, this issue is important to address if coins and tokens are to be taxed similarly to a lex specialis category.

In summary, there is a presumption that cryptocurrencies should be classified as assets held for capital investment and speculative purposes regardless of the underlying economic substance. Compared to established investment alternatives, for example, shares, securities and official currencies, the taxation of coins and tokens is unfavourable. Similarly, issuing tokens via an ICO is less beneficial for tax purposes compared to traditional means of raising share capital. For neutrality purposes, it can be argued that coins and tokens with the economic substance of, for instance, a share should be taxed as such. Differences in taxation due to the current regulation not being adjusted to the underlying technology of cryptocurrencies is not in line with the principle of neutrality. The issuance of coins and tokens via ICOs is largely unregulated, which displays an important difference to traditional investment alternatives. Therefore, reporting requirements and IPO regulations (e.g. via a mini IPO) could be considered without distorting the cost-effectiveness currently associated with ICOs.

\section{Conclusion ANd Perspectives}

Cryptocurrencies hold great potential in terms of improved efficiency of transactions between parties and reduced transaction costs due to the re-movement of intermediaries. Generally, the technology reduces the administrative burden for the involved parties. ICOs facilitate faster and more inclusive capital formation compared to IPOs due to the participation barriers being lowered since small investors from all over the globe are allowed to invest in the ICO. However, all these elements of potential may not be realized if the taxation of coins and tokens is unfavourable compared to established alternatives, such as shares, securities or official currencies. In both Denmark and Sweden, current tax law may hinder the use of cryptocurrencies for several reasons.

In general, the lack of regulations and case law leads to significant uncertainty in respect of the taxation of the investor and the issuer - particularly concerning tokens. Although specific tokens may be classified differently, there is a strong presumption that cryptocurrencies will be treated as assets held for capital investment and speculative purposes in both Denmark and Sweden. Out of the four different categories of cryptocurrencies analysed in this article, utility tokens and asset tokens are most likely to be classified in other income categories depending on the construction and purpose of the specific token. Compared to other investment alternatives, the classification of cryptocurrencies generally results in the application of less favourable rules on the taxable income and deduction rights. The realization of the full potential of ICOs as a cost-efficient way of raising funds is likely hindered as the issuing company generally will be taxed on financing as opposed to issuance of shares or bonds.

For neutrality purposes, it can be argued that coins and tokens with the economic substance of, for example, a share or a security should be taxed as such. Another way of increasing neutrality could be to include new rules that specifically considers the underlying economic substance of coins and tokens. An important difference to traditional investment alternatives is that the issuance of coins and tokens may fall outside current compliance and reporting regulation. Reporting requirements and IPO regulations (e.g. via a mini IPO) could be considered. Looking forward and assuming that no lex specialis rules on the taxation of cryptocurrencies are adopted, most potential seems to lay in utility tokens and asset tokens since they hold a possibility of being taxed in accordance with their economic substance. 